\title{
A CASE OF MAXILLARY CANCER IN A TWELVE YEAR OLD BOY
}

By

Prof. T. GOTO. AND J. MURASHIMA

From the Department of Oto Rhino.Larngology

(Prof. T. Goto) University of Nagasaki, School of Medicine

\begin{abstract}
A Case of maxillary cancer ih a twelve-year-old boy was repoted.
Histological examination revealed a basal cell carcinome. ray irradiation, totally $3150 r$, was given preoperatively and radical redical resection of the maxillary bone and radical neck dissection were carried out under endotracheal anesthesia. The postoperative course had been smooth and 2 years after the operation; no recurrencc was seen.

Maxillary cancer in children under twenty years of age is very rare: In this age group only 6 cases have been reported in Japan and among 1011 cases of maxillary cancers collected from the literaturs only 3 were under twenty years of age. The prognosis of these cases in general is poor.
\end{abstract}

\section{2 才の上顎 癌}

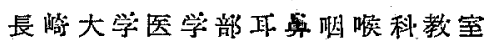

教授、後、藤繁郎・村島二郎

上顎癌は 50 才代にも最も多く見られるのであるが， 近時癌腫の診断の上に若年者に発生する癌腫が注目され るに至つた・上顎癌むまた比較的若年者に見られること も既に知られてはいるが，最近，12 才の上顎癌症例に 遭遇した．年令的には交献の上では極めて稀であつた が，気管管内麻醉下に上頻の全摘術を行って 2 年後な特 再発をみないので報告し併せて若年者の上頸癌に就て考 祭することにした。

症例：12 打男子. 初診昭和 31 年11月12日. 約 10 力月前に左煩部に軽度腫脹を認好菌利医より煩菌肉触 譬に試験的に切開を受け上顎内 埋伏雨によるるのと診

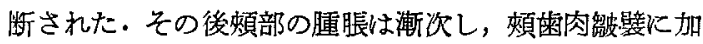
えられた切開創も瘦孔を形成するに至つて当科儿紹介さ

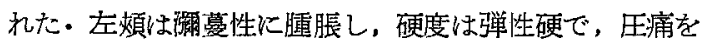

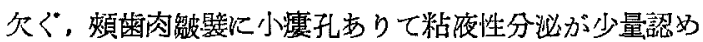
られる．消息すると骨を欠損し，肉第上う組織にふれ

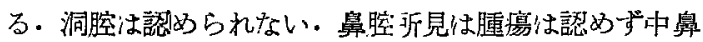
道に粘夜膿性鼻漏打等量を認める. 後舜鏡的にも腫瘍が 見られない，腫場の疑いで試験的に上嵿洞を開放すると

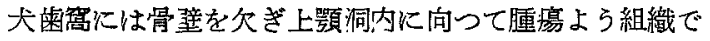
充满されていた・レ線険查の結果その腫脹は樑部後方及
は笠骨蜂集の方への進展はなく寧万外部に向つて增殖乙 ているように見られた。

病理組織像（別紙写真）：犬小の核を有する上皮性の 細胞が多数の癌栄を形成しているが，癌巣の中心部の細 胞は少しく丸味を帯びて特り，これ等の細胞は Chromation に富んでいる。有棘細胞は認められず角化の傾向 なく基底細胞癌と診断された。

放射線招射後に手術を行うことにした。

術前頼部及び左側頸部から45 日間仗 X 線 3150Y（表 面量) 照射を行つた。照射後 4 日目に気管内麻䣲下に栭 部リンパ源清術に続き上䫈全摘術を実施した。

手術所見：節骨䗋笨，眼窝，頭蓋底の方向には浸潤

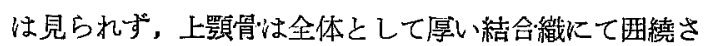
れていたために一つの塊として切除摘出できた．翼口蓋 窝にも浸閵は見られず頭蓋との間は結合織の被膜化のた 枌離された－硬口盖の部て正中線を多少越えて 反刘側の口蓋板の骨葡が線䊒泩に变化して見られたの で，この部は念のために広く鐅除しラジウム針を插入し て颃いた。

\section{考按}

上影癌の発生の年令的関係を文献及び教室の統計から 


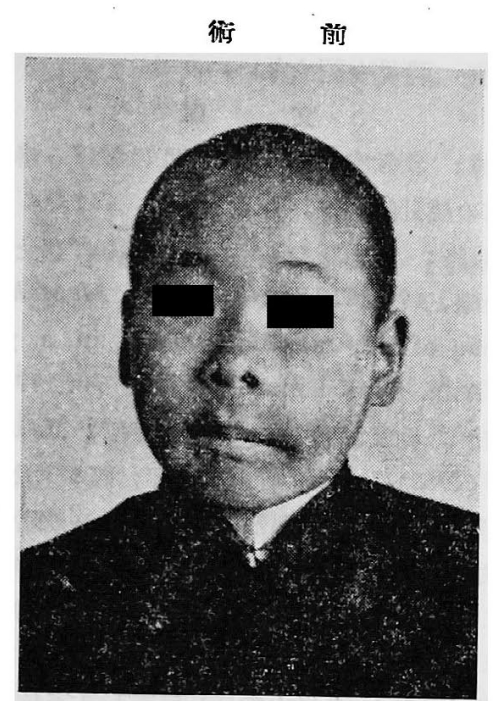

摘出上啹管

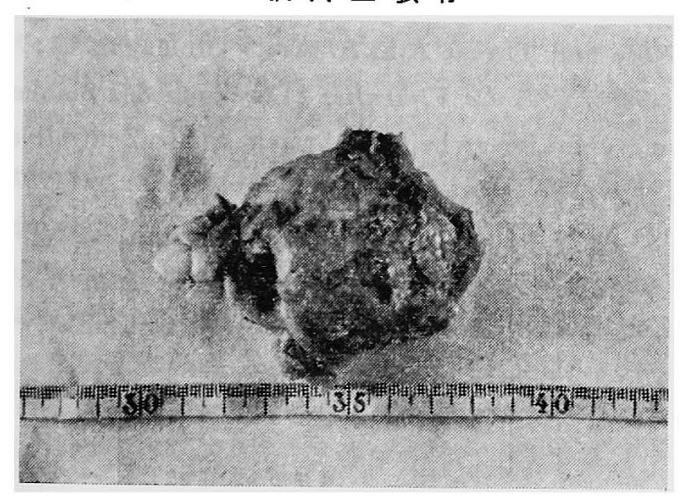

若年考上類澏年令別統計

\begin{tabular}{|c|c|c|c|c|c|}
\hline 若 & \begin{tabular}{|c|}
$\frac{4}{4}$ \\
0.9
\end{tabular} & & $\frac{3(t)}{20.25}$ & 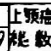 & \\
\hline 月 7 & & & 1 & 55 & \\
\hline 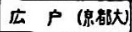 & & & 5 & 137 & \\
\hline$山 川(大 \bar{r})$ & & & 1 & 160 & $1933-1942$ \\
\hline 小林体确) & 1 & & 2 & 147 & $1946.9-1951.11$ \\
\hline (* 国) & & & 7 & 92 & 1935 1954 \\
\hline 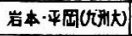 & & 3 & 8 & 294 & $1936=1955$ \\
\hline 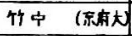 & & & 2 & 62 & $1925 \sim 1955$ \\
\hline 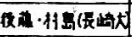 & & 1 & 2 & 64 & $1949=1958.3$ \\
\hline & 1 & 4 & 22 & 1011 & \\
\hline
\end{tabular}

調查すると別表の如く，上顎癌症例総数 1011 例のうち で最も多数を占める年令は 50 才代で $31.2 \%$ である. 若 年者には少く 29 才までのものは 27 例 $(2.6 \%)$ 飞見られ るが，10 寸代のものには 4 例 $0.4 \%$ 認められている.
街 後(2 年後)

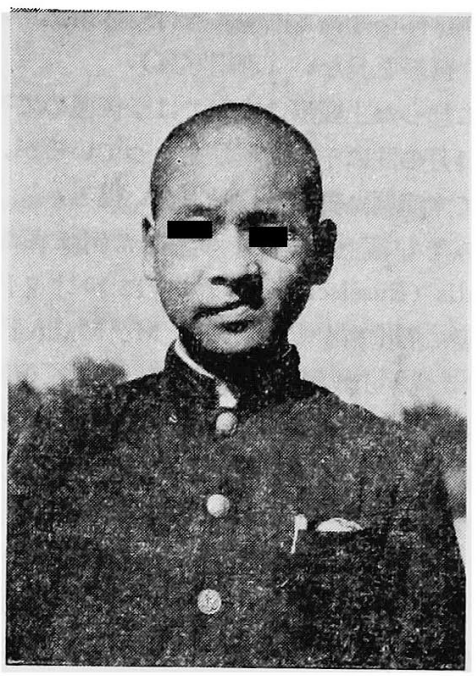

基底湖胞癌癌桼

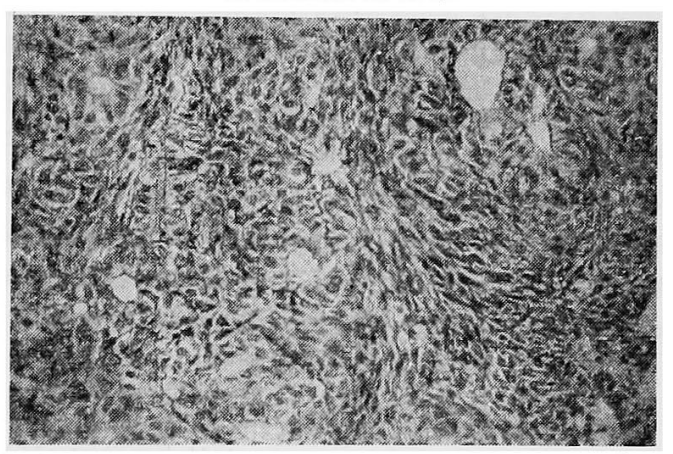

若年者の上罘癌の症例のみを文献に求めると，鳥居氏

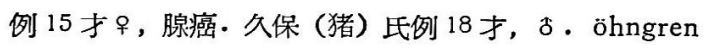
例 25 才。，扁平上皮癌. A.Kalis 例 13 才。，丹柱上皮 細胞性腺癌. J. Mo $\mathrm{M}_{\mathrm{AHON}}$ 例 20 才果, 扁平上皮癌.

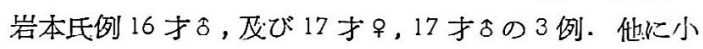
林氏の满 2 年 9 カ月の 幼女の単純癌と De Vincentis (Perugia) の 2 才幼女の硬性癌の報告例が見られるのみ である。

癌腫の早斯颜断が絶対重要視されている今日，僅少な がら斯る若午者にも上顎癌が発生し得る事は診断ひいて は沿潦上一考を要する。

本症例の術後経過：本症例は前述の如く術前 $\mathrm{X}$ 線照 射を行い，栭部淋巴節廓清，上顎全摘術を実施し，術創 部にラヂゥム照射を追加したのであるが，本症例は癌浸 
潤が外来部に限局堌殖し手術により・全摘出し 得たため か，本症例は幸い手術も円滑に施行で法後 2 力年を経 過した現在再発を見ない（別紙写真).

若年者に起つた上顎癌は交献では予後極めて不良でい ずれも短日月の間に不幸な転帰をとつているが，その意 味に执いて本症例は貴重な経験と云い得る・

交献をみても観血的滰法を実施した例は甚だ少く， S. A. Kalis (Russisch) が1951 年に13 守円柱上皮

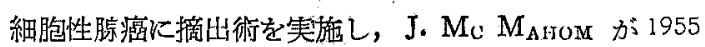
年に 20 才。庣平上皮癌に上顎内容除去を反復施行して いる・本邦では岩本氏が17才る例に上顎全摘術を実施し た報告が記戟されている。このうち J、 $\mathrm{M}_{\mathrm{C}} \mathrm{M}_{\mathrm{AH} O \mathrm{~N}}$ 及 び岩本氏の例は術後約 5 カ月で不良な転帰をとつてい るが, S. A. Kalis $\sigma$ 例は術後 8 カ月の観察では再発を 認めないと記述されているがその後のことはわからな い. 本症例では術後 2 カ年経過の現在再発が認められな いが，その理由を考えると，癌の性質が腙癌であつたこ とが大きいと考觉ざるを得ない，上顎の腺癌は発育緩慢 で転移の傾向が少く， expansiv に良性腫瘍上うの増殖 の仕方をすることが知られている.本例る結合織による 被覆他がつよく、これにレ線の照射を行つたために更に その傾向を堌加し，手術時によく被賈化された塊として 全体的に取り出すことができた.いずれにしても頸部廓 清手術についで上顎切除術が危険なく行われることので きたのは気管内麻酥によることができたためである。

\section{結一語}

12 才男子の上顎癌（基底細胞癌）例を報告した。洏 前 $\mathrm{X}$ 線照射 $3150 \gamma$ を行い 4 日後に気管内麻酔下で頚部
リンバ簛敦清術及び上䫑の全摘術を実施した・術後 2 カ 年を経過して再発を認めない。

\section{文献}

1) 土并博：我教室最近 10 力年間によ゙ける类腔及び副

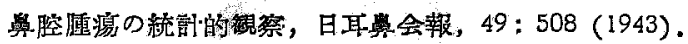

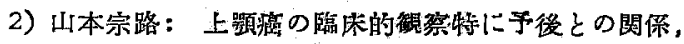
日耳.楞会報, 49: 1019 (1943). 3) McMahon, B.J.: Carcinoma of the maxillary sinus in a youth of twenty Ann. Otol. Rhin. Laryng, 64: 777 (1955).

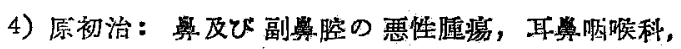

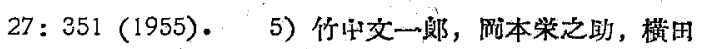

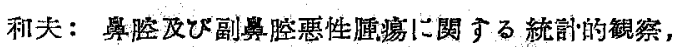

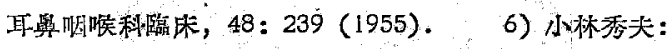

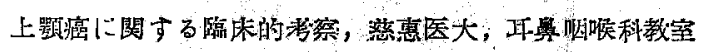

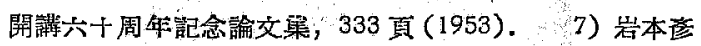

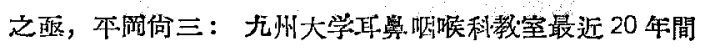

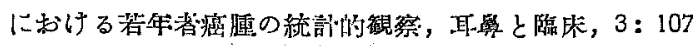
(1956). 8) Kenneth D. Devine: Tumor of the Nose and Throat A.M.A. Arch- Otolaryng. 67:716 (1958). 9) De Vincentis: Carcinom des Siebbein und oberkiefers bei 2 jahrigen kind. Zentralblatt für Hals-Nasen und Ohrenheilkunde 57 : 59 (1957). 10) S.A. Kalis: Ein Fall von Oberkieferksebs bei einem Mädchen von $13 \mathrm{~J}$ ahren. Zentralblatt für Hals-Nasen und Ohrenheilkunde 45 : 259 (1952).

（原稿到着 $=$ 昭利 34.2 .4 日） 